\title{
Rahab in the Book of Joshua and other Texts of the Bible
}

\author{
Obiorah Mary Jerome \\ Department of Religion and Cultural Studies, University of Nigeria, Nsukka, Nigeria
}

\begin{abstract}
Christian Sacred Scripture embodies some puzzling episodes which human minds can grasp only through similar faith that inspired its writers. The story of Rahah, presented as a prostitute in the Book of Joshua, provides such enigma. This woman rose from being a prostitute to a heroine for she was numbered among the Ancestresses of Jesus Christ. Her singular manifestation of faith in God and subsequent interpretations of this in the two parts of the Christian Bible are the focus of this paper. It is discovered that God's ways are not our ways, for the Creator can choose anyone and at any time to accomplish his design.
\end{abstract}

Keywords: Faith in God, Jericho, The Book of Joshua, Rahab, Spies

\section{INTRODUCTION}

At its face value the New Testament perspectives and interpretations of Rahab's story and personality as presented in the Book of Joshua appear surprising or even misapprehension of reality. She was a marginal woman with unusual character. In fact, the Hebrew version of Joshua 2 describes her as 'iššăh zônāh - a professional secular prostitute distinct from qědēšāh - "sacred prostitute"; the latter would have been more respectful. It is instructive to observe that the texts of the New Testament and early Christian writers that appropriated the attitude of this woman towards the Israelite spies in projecting their theological thrusts preserve her Old Testament designation or identity when they still describe her as hē pornē "prostitute".

Still at the apparent value of the personality of Rahab, this woman as presented in Joshua, particularly when perceived from the point of view of her people, was far from being patriotic in the real sense of the word. Does she not appear as a traitor who could be charged of treason against her own people? She betrayed her people by disclosing to the prospective invaders of her city the state of mind and the anxiety of the inhabitants. Furthermore, her action seems to portray some selfishness detrimental to her own people. She cared only for herself and her immediate family. She was solicitous only about saving her life and her family. Rahab went to the extent of abandoning her own belief and professing foreign religion of the looming invaders. This was the woman who boldly lied to the king of his people and daringly made fool of his envoys. She preferred to save strangers rather than to identify with her people.

In the extra-biblical Jewish literature, Rahab is portrayed as a heroine, a model proselyte and a worthy ancestress of important people. Could this be what infiltrated into the New Testament writings? She prominently appears in three significant New Testament texts. Firstly, as one of the few women whom the Gospel according to Matthew included in the Genealogy of Jesus (Matthew 1:5). Secondly, the author of the Letter to the Hebrews (11:31) presents her as a prototype of faith in Israel. Finally, in the Letter of James (2:25) Rahab is an example of faith with good works, for in believing in the Lord she received the spies in her house. She and Sarah, Abraham's wife (cf. Hebrew 11), are the only women in these lists of heroes of faith in the Bible, specifically in the Old Testament.

Rahab's confession of faith in Joshua 2:9-11 depicts a characteristic protestation of faith found in the Old Testament which often recalls God's great acts of love; this formed the core of its confession of faith and broadened its gaze in faith [1]. She confessed her faith like any other Israelite by recalling the great deeds of the Lord and their effect in the present. By so doing she identified with them and became one with them in their faith. She became a member of the Yahweh community for in the Old Testament, "the faith of Israel was seen primarily as a relationship between the faithful community and Yahweh. It was not a 'conversion' experience that brought individuals to faith. It was their inclusion in the community of Yahweh, the People of the Lord" [2].

What is special about Rahab the prostitute? What kind of faith did she have? How can one reconcile this perceptible faith of Rahab with her attitude towards her own people, especially from the perspective of the inhabitants of her city? What can we learn from Rahab especially now that the Church encourages all to reflect on the nature of Christian faith and embark on assiduous study of its contents? These and many other questions are what have motivated this research. It is a quest to understand the nature of the faith of an unusual woman who rose from being marginal to the fore, and to the point of being a worthy ancestress of Jesus the Messiah. This research adopted a literary method with emphasis on the analysis of key narrative techniques employed in the text. 


\section{Rahab in the Book of Joshua}

In the entire Old Testament the personal name Rahab occurs only in the Book of Joshua and significantly in the narrative on the fall of Jericho into the hands of the Israelites. Major events in the history of the people of Israel were later recounted in hymnic and sermonic recitals like 1 Samuel 12; Nehemiah 9:6-31; Psalms 78; 105; 106 and 136; but Rahab's contribution to Israel's history remains conspicuously absent in these and in other parts of the Old Testament. It is also striking to observe that some key events in Joshua are not mentioned in any other part of the Bible. These include the fall of Jericho, the capture of Ai, the division of the land and the covenant at Shechem. Is the Book of Joshua so isolated? It is expedient to begin a comprehensive study of the role Rahab played in the success of Joshua's leadership with a survey of other features of the book of Joshua. Her faith which is the focal issue of this research is intrinsically intertwined with her contribution to Joshua's conquest of the Promised Land.

\subsection{Some Features of the Book of Joshua}

A fundamental feature of the Book of Joshua is a chain of parallels that the writer deliberately created between some events in the life of Moses and Joshua son of Nun, Moses' minister and successor, according to Coogan [3]. Both leaders, for instance, sent spies to reconnoitre the land God promised the Patriarchs (Numbers 13; Deuteronomy 1:19-46; Joshua 2). Both leaders experienced the miraculous drying up of Reed Sea and River Jordan respectively (Exodus 14; Joshua 3). They conducted a celebration of Passover to mark important stage in their lives as leaders (Exodus 12; Joshua 5:10-12). Each had a vision during which they were commanded to remove their shoes from their feet for the land on which they were standing was a holy ground (Exodus 3:5; Josh 5:15). Both leaders sent spies for the second time (Numbers 21:32; Joshua 7:2-5). Moses and Joshua were great and persistent intercessors who when held out their hands in prayer their people prevailed over their enemies in battle (Exodus 17:8-13; Joshua 8:18-26). They also interceded for them when their people offended God (Exodus 32:11-14; Numbers 11:2; 14:13-19; Deuteronomy 9:25-29; Joshua 7:6-9). They prepared their subjects for theophanies (Exodus 19:10; Joshua 3:5). The two leaders distinguished themselves as mediators of the covenant between God and Israel (Exodus 24; Joshua 24). Finally, these ideal leaders of Israel delivered farewell speech just before they died (Deuteronomy; Joshua 23-24) [4].

All these close parallels are so arranged in such a way that they justify the divine assurance to Joshua articulated as direct speech in Joshua 3:7: "This day I will begin to exalt you in the sight of all Israel, so that they may know that I will be with you as I was with Moses". In Joshua 4:14 the narrator re-iterates this divine declaration in these words: "On that day the Lord exalted Joshua in the sight of all Israel; and they stood in awe of him, as they had stood in awe of Moses, all the days of his life". We have in this and in the parallels mentioned above a major theme in the Book of Joshua. There was a pronounced continuity between the leadership of Moses and that of Joshua. These parallels between Moses and Joshua his assistant and successor are reminiscent of similar parallels in the narratives on Elijah and Elisha in 1 Kings 17-2 Kings. Moses was successful and Joshua who worked closely with Moses as his special aide would also be successful. It was God's will, according to the narrator, that Rahab would contribute immensely to this success.

Another outstanding feature of the Book of Joshua is that Joshua son of Nun and direct successor of Moses is presented in the book as one who fulfilled Moses' injunctions. Some of these are: In Numbers 32 and Deuteronomy 3:12-20, Moses commanded that Reuben, Gad and the Eastern Manasseh should join other tribes in the military conquests of the Promised Land. Joshua faithfully fulfilled this in Joshua 1:12-18. Moses also instructed that an altar be erected on Mount Ebal (Deuteronomy 27:1-26); Joshua executed this by building an altar on that mountain (Joshua 8:30-35). Moses ordered the extermination of the inhabitants of the land and of the Anakim (Deuteronomy 20:16; 9:2). Joshua obeyed; this forms a greater part of the narratives we have in the Book of Joshua. Rahab was instrumental in one of such conquests. She was in a very good position to foil Joshua's plan but she supported the divine plan as conveyed by Moses and understood by Joshua and his people. Furthermore, the division of the land by lot which Joshua did in Joshua 14:2 was in accordance with the command he received from Moses, his predecessor in Numbers 34:13. In Numbers 35:9-15 and Deuteronomy 19:1-10 Moses instructed that cities of asylum be established; Joshua obeyed (Joshua 20). Similarly, cities of the Levites built by Joshua (Joshua 21:1-42) were also in fulfilment of Moses' injunctions (Numbers 35:1-8). In fact, at a point in the narrative, the narrator summarised all these commands and their fulfilment as follows: "As the Lord had commanded his servant Moses, so Moses commanded Joshua, and so Joshua did; he left nothing undone of all that the Lord had commanded Moses" (Joshua 11:15). This confirms that Joshua's actions were not merely a fulfillment of Moses' injunctions; rather, they had their origin in God, who commanded Moses and Moses passed them on to his successor. Rahab's episode was also not excluded from this divine plan.

Frequency of aetiological conclusions in the Book of Joshua marks this literary device as a noteworthy feature in the book. Aetiologia is used when, either directly or indirectly, the speaker renders a reason for what he thinks, says, or does. Its Latin name causae redditio further clarifies the meaning of this figure of speech, for it means "rendering a reason" or "showing the cause" [5]. There are a good number of aetiological narratives in 
Joshua and they often end with the phrase "ad hayyôm hazzeh "to this day" or other variants (cf. Joshua 4:9; 5:9; $6: 25 ; 7: 26 ; 8: 28 ; 9: 27 ; 10: 27 ; 13: 13 ; 14: 14 ; 15: 63 ; 16: 10)$. The phrase 'ad hayyôm hazzeh "to this day" seems to indicate that the events narrated took place in the distant past; the episodes we have in Joshua were written many years after. It is informative to note that the narrative on Rahab bears this aetiological mark. In Josh 6:25 the narrator adds: "Her family has lived in Israel ever since. For she hid the messengers whom Joshua sent to spy out Jericho". This answers the question: why does Rahab live in Israel? And the answer is also in the text: she contributed positively to Joshua's expedition. The rest of the story is in Joshua 2 where she made her act of faith corroborating it with good work and in chapter 6 where she was rewarded for her good work.

Following the tripartite division of the Book of Joshua in I. The Actual Conquest (chapters 1-12); II. The Division of the Land (chapters 13-21); and III. Appendix (chapters 22-24) [6], Rahab's episode is found in the first part of the Book. This first part concentrates mainly on the conquest of the land by Joshua and Rahab contributed to its success in a very significant way. She helped in its success and in accepting the faith of the invaders thereby being instrumental in opening the door of faith in YHWH to non-Israelites.

\subsection{Narrative on Rahab in the Book of Joshua}

In the Book of Joshua, Rahab is mentioned in chapters two and six. She made her act of faith in chapter two and reaped the benefit in chapter six. Actually, the full narrative is in chapter two for she appears only towards the end of chapter six. A detailed study of chapter two and the concluding section of chapter six (Joshua $6: 17,22-25)$ that forms a sequel will elicit the features of the personality of Rahab and the faith that made her rise from the status of a marginal to a heroine.

\subsubsection{The Text of Joshua 2}

The Masoretic Text of Joshua 2 differs from other ancient versions of this chapter, particularly the Septuagint. In v.1, for instance, the adverb hereš "secretly" is not found in the Septuagint and the Syriac versions. However, the two men sent by Joshua actually embarked on surreptitious mission for they arrived at dusk and spent the night in a house that was suspicious. The inhabitants suspected their movement and raised an alarm. Still in v.1, the insertion of the name of the city Jericho, by the Septuagint and suggested by Masoretic Text, immediately after the verb wayyābo $\bar{o}^{\prime} \hat{u}$ "and they came" seems to attenuate the sexual implication of this verb in the context. The verb bô' "to come", "arrive" etc., is sometimes used in the OT to indicate co-habitation of a man with a woman. Sarai used the same verb to introduce Abram to her maidservant, Hagar, in Genesis 16:2 [7].

In the same manner, in v.3, the Septuagint omitted a part of the words of the king's messenger to Rahab: hôṣ̣̂̂î hā'ănāšîm habbā'îm 'ēlayik 'ăšer bā'û $1^{\text {e }}$ bêtēek "Bring out the men who have come to you, who entered your house". The Septuagint carefully removed 'èlayik 'ăšer bā'û. From the point of view of the translation in Septuagint, the emphasis is on entering the house of Rahab. Even from this early stage the scribes, as we will see below in Jewish extra-Biblical writings, had already begun presenting Rahab positively.

In verse 9 , the phrase that seems like an extreme negative presentation of the inhabitants of Jericho by Rahab is also omitted in the Septuagint. According to the Masoretic Text, Rahab had this to say about her own people: w w k̂i nāmōgû kol-yōše bê hā'āreș mippenêkem "and that all the inhabitants of the land melt in fear before you". That this phrase is deliberately omitted by the Septuagint is justified by its presence at the end of the chapter, in v.24 where it is repeated in the report the spies gave to Joshua.

The syntactic construction in v.2 elucidates the reaction of the people: hinnēh 'ănāšîm bā'û hēnnāh "behold some men came here ..." We have here a presentative exclamation in exclamation of immediacy and fuller exclamation of perception. Hinnēh "behold" in this context has the nuance of vivid immediacy in a verbal clause [8]. When the men came and entered Rahab's house the people reported it to their king. The use of this exclamation is meant to heighten Rahab's denial of a fact that was obvious.

Besides these textual variants, Joshua 2 anticipates some of other narratives in the book. Firstly, there is another reconnaissance in chapter 7. Secondly, Rahab's confession of faith has some affinity with similar confession of faith by the Gibeonites in chapter 9. Thirdly, Rahab's speech encapsulates the pivotal points in Joshua's farewell speech in chapter 24. In point of fact, Joshua 2 has been described "as a prolegomenon to the events that follow" [3]; it serves as a hinge that holds vital episodes in Joshua.

\subsubsection{Literary Structure and Narrative Devices}

There are some characteristic features that contribute to the clear delimitation of the narrative we have in Joshua 2. Firstly, its content or theme is different from those of the two chapters that flank it. Joshua 2 focuses on the reconnoitring of Jericho by the two men sent by Joshua. Secondly, some of the characters in this chapter (Rahab, spies, inhabitants of Jericho and their king) are not mentioned in the two adjacent chapters. Thirdly, the scene of the action is Jericho. Considering these points, we have a distinct narrative which is also 
linked to other narratives in the book. In fact, Joshua 2 is concluded in chapter 6 . We have also seen above how this chapter prepares for other events in the book of Joshua.

Like many other narratives in the Old Testament, Joshua 2 begins with an exposition which "is the presentation of indispensable pieces of information about the state of affairs that precedes the beginning of the action itself. These details are necessary for the understanding of the narrative" [9]. Verse 2 of our text seems to serve as an exposition. In this verse, the theme of the narrative is introduced in the words that Joshua addressed to the two men: $1^{\mathrm{e}} \underline{k} \hat{u} \mathrm{r}^{\mathrm{e}}$ ' $\hat{\mathrm{u}}$ 'et-hā'āreș w ${ }^{\mathrm{e}}$ 'et-y $\mathrm{y}^{\mathrm{e}}$ rîhộ “Go, view the land, especially Jericho". Again, the characters and the scene of action are introduced. In this exposition, it is necessary that the narrator uses the adverb hereš "secretly". The secrecy of the spies' action triggered the suspicion from the inhabitants. Furthermore, this secrecy continues in the rest of the story: they entered Rahab's home at night; she hid them, and secretly sent them away; they secretly hid themselves for three days so that they would not be discovered by their pursuers.

"Exposition" usually gives only necessary information that helps the audience to understand the narrative thrust of the text. This might explain the reason why the narrative time (the duration of the actions and events in the story as measured in units of real time) in this verse is conspicuously shorter than the narration time (material time necessary to tell the story) [9]. The journey of the spies from Shittim to Jericho is simply mentioned in passing; there is no need for a detailed description of what happened on the way. Shittim is about six miles from the River Jordan [10], and from Jordan to Jericho is also another distance. The length of time it took them to reach Jericho and possible things that could have happened to them are not necessary for the narrative. Such "omission" could also be understood as ellipsis. "There is an 'ellipsis' in a narrative when events of the 'story' are simply bypassed in the "discourse"" [9].

Dialogues play an important role in the internal structuring of the narrative and in every segment of Joshua 2 Rahab is projected as the chief character. The first scene, which is also the set of dialogue, took place in the house of Rahab and it begins from v.2 through v.7. Besides the reported speech of the message sent to king of Jericho: "some Israelites have come here tonight to search out the land", the first dialogue was between this king, through his envoys, and Rahab. She was commanded to bring out the men (v.3). She responded, lying and misleading the king's emissaries (v.4). Her words and actions propelled the narrative. They wanted to move her to action but she ironically ordered them to obey her; she actually and humorously fooled them. The men rushed out of her house with the intention of capturing the two spies whom she carefully hid in her house. At the centre of this scene is her lie which the king's messengers believed to be true. Verses 2-7 contain the scene of the saving lie of Rahab for her lying saved the two Israelites.

Scene two is again centred on a dialogue between Rahab and the two spies in vv.8-14 and it was situated in Rahab's house, but in a specific spot in this house, the roof. It was within this dialogue that she made her profession of faith in the God of Israel (v.11). Secondly, she dominates so much in the dialogue (vv.9-13); in a scene of seven verses, her words alone occupy five verses. In addition, this scene prepares for the long speech of the spies before their departure; she made them swear that they would preserve her life and that of her relatives.

Scene three took place at the outer side of the city, beside the wall of the city (v.15) and it is from v.15 to v.21. Just like in the first scene, in this third part of the narrative, Rahab instructed the two men on how to escape. Her instruction in this one differs from that of the first part for it is not an irony as in the previous, but on how to escape successfully from the pursuers. The protracted speech of the spies was on the condition given to Rahab for the fulfilment of the oath she made them swear (vv.17-20). In part 2, Rahab had a long speech and the spies briefly responded. In part three, she initiated the conversation, the spies spoke at length, and she responded them briefly (v.21).

Verses 22-24 narrate the return of the spies to Shittim and their report to Joshua. It is revealing to note that even in this concluding part of the text Rahab is still very much active. The words of the report given to Joshua were taken from her speech in v.11. The leitmotif is the figure of this very clever woman who defies every intimidation coming either from her people or from the strangers who entered her house; to the former she employed wit and for the latter she fully identified with their mission and did all possible to make it successful. She pervades all the segments of the narratives which can be divided thus: a) The Exposition (v.1); b) verses 27 ; c) verses 8-14; d) verses 15-21; e) verses 22-24. Verse 1 corresponds to vv.22-24 in the sense that the first is the preparation for the project and the second is its accomplishment. Again, Part two and Part four are related. In the first one, Rahab sent the king's envoys away to pursue the spies, in the second she sent the spies away so that they could escape from the pursuers. The centre of the narrative is vv.8-14 where Rahab made her profession of faith and she also made the spies swear an oath to save her and her family from destruction.

\subsubsection{Close Reading of Joshua 2}

\subsubsection{The Exposition (v.1)}

This introduces the narrative, stating the theme and presenting the key characters. Joshua was the initiator of this reconnaissance; by this action he exhibited an aspect of his as Moses' replica. In Numbers 13 
and at the threshold of the Promised Land Moses sent spies to scout the land of Canaan. At the Lord's instruction, he sent twelve men, each from the twelve tribes of Israel; all their names are given in Numbers 13. Joshua, who before this mission was called Hoshea, represented the tribe of Ephraim. As Moses successor, he also sent only two spies whose names are not mentioned in the text, probably because it is not important for the narrative. They were sent from, according to the Hebrew text, haššiț̣im Shittim. This proper name consistently goes with the definite article, and it means perhaps "the acacias" [11]. Shittim was Israelite camp, east of the Jordan and north-east of the Dead Sea, before they entered the Promised Land. Like Moses, Joshua had to send the spies when the people were nearing the land of Canaan.

The mission of the two men was to go and view the land, specifically Jericho, which is in the northwest of the Dead Sea and the first city the people of Israel conquered when they entered the Promised Land. It is significant for the narrator that this first possession of Israel was through Rahab's encouragement. Jericho is a very fertile and ideal place for settlement. This was where Rahab lived with her family, and probably engaged in some useful faming besides her social work as a prostitute. Jericho is frequently mentioned in both Old Testament and the New Testament. It occurs about seventy times in Old Testament and New Testament (cf. Numbers 22:1; 26:3; Joshua 2; 5:13-6:23; 16:1,7; 18:12,21; 2 Kings 2:4-5,15; Jeremiah 39:5-7; Matthew 20:29; Mark 10:46 etc.). It is known for its date palm trees that merited its name as "City of Palm Trees" (Deuteronomy 34:3; Judges 3:13; 2 Chronicles 28:15). Jericho had a wall round it with a gate that could be closed (Joshua 2:7). The city lies about eight hundred and twenty-five feet below sea level and is in the region that is the lowest spot in the world [12].

The narrative in Joshua 2 centres on Rahab; nothing is said about how the spies viewed the land as directed by Joshua in v.1. As soon as they entered Rahab's house, according to the narrator, she became the focal point, everything revolves around her. In the Bible, the name Rahab refers firstly to this woman who is depicted as the prostitute of Jericho. In Hebrew the root of this name is RHB meaning "to be wide" or "to be broad". Some explain it as an apocopate form of the theophoric personal name Rehabiah that means "YHWH increases" or "enlarges" $[13,14]$. Secondly, in the Bible the name Rahab refers to a mythological sea serpent or dragon, "boisterous one", similar to Leviathan which was originally Canaanite chaos monster (cf. Psalms 87:4; 89:11; Job 9:13; 26:12; Isaiah 30:7; 51:9). This name with this second meaning serves as a metaphorical name for Egypt [15]. The Rahab we have in Joshua 2 is a feminine personal name of the protagonist in this narrative. She is called 'iššāh zônāh literally "a woman prostitute". Zônāh is cognate with the verb zānāh which "is the usual word for the activity of a harlot or prostitute" [16], and used figuratively for apostasy in the Old Testament. In Joshua 2, Rahab is known as a prostitute and she earned her living through this unpopular way of life.

The spies, $m^{\mathrm{e}}{ }^{\mathrm{ragg}}{ }^{\mathrm{e}}$ lîm, from Shittim came secretly and entered, wayyābōô'û, her house and lay down or

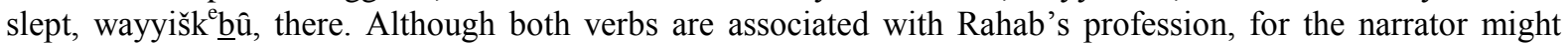
intentionally have euphemised it. The verb šākab is often used in the Old Testament for sexual intercourse (about fifty-five times; cf. Exodus 22:15,18; Leviticus 15:24,33; 18:22; 19:20; 20:11,12,13,18,20; Numbers 5:13,19; etc. The inhabitants of Jericho still recognised them as Israelites, perceived their coming as spies and alerted their ruler. The two verbs for "to enter" and "to lie down" or "sleep" further emphasise the type of woman Rahab was, prepare and elucidate her profession of faith later in the narrative. The two men are described as $m^{\mathrm{e}}$ ragg ${ }^{\mathrm{e}}$ lîm, spies, the plural of $\mathrm{m}^{\mathrm{e}}$ raggēl, a derivative of the denominative verb rāgal (substantive is regel foot) "to spy out" (cf. Genesis 42:30; Numbers 21:32; Deuteronomy 1:24; Joshua 6:22,25; 7:2; etc.). A spy, m raggēl, according to Old Testament understanding, is a person whose feet are all too busy [17]. Rahab received them and positively directed them. Her compatriots, however, were wary about the movement of these two men and did not hesitate to capture them.

\subsubsection{The saving lie of Rahab (vv.2-7)}

This first part of the narrative contains the first set of dialogue in which Rahab plays a vital role. The presence of the men within the wall of Jericho was of great concern to all and a threat that the king should know about; he was actually informed in these words: hinnēh 'ănāšîm bā'û hēnnāh hallaylāh mibb ênê yiśrā'ēl laḥpōr 'et-hā'āreș "behold men have come here at night from among the Israelites to scout out the land" (v.2). Hallaylāh "at night" in this direct speech continues the adverbial phrase "secretly" of v.1 and was perhaps what elicited fear in the inhabitants of the city. The king of Jericho acted prompted, according to the narrative, and sent orders to Rahab to bring out the men (v.3). Rahab's reaction was to hide them (v.4); the narrative reveals later in v.6 how he concealed these two men. In v.4a, she hid them in her actions, while her words in vv.4b-5a further concealed them and convinced both the king and her subjects to believe that the men were no longer within the walls of the city [18]. Rahab refused to do the will of the king and the rest of the inhabitants of Jericho. Her answer to the king of Jericho is reminiscent of that of Shiphra and Puah to the Pharaoh in Moses' infant narrative (Exodus 2:19). Just as these Hebrew midwives deceived Pharaoh, Rahab cleverly saved the two 
Israelites. She did this because of her faith in their God and mission which she would express later in the narrative.

It is interesting to observe how Rahab achieved her objective and outmanoeuvred the king and his envoys. She agreed first that men entered her house: kēn bā'û 'ēlay hā'ănāšîm "yes the men came to me". She used the words of the command she received from the king; while she carefully avoided using the phrase šenayim 'ănāšîm "two men" which the narrator uses in the first part of v.4 and in v.1. It seems in the narrative that it is only the narrator and Rahab who know the number of the men that came for this specific purpose of scouting the land. This is because in the report given to the king and in the words of the king's command (v.3b) they are simply called "men", without the modifier š nayim (two). It is possible that the inhabitants of Jericho were not sure of the number that came to spy their city. This could explain why Rahab had to remain on their level of knowledge in her response. She acknowledged that men entered her house (v.4b), perhaps like any other men whom she used to serve. The first part of her deceit might appear innocent: w ${ }^{\mathrm{e}} 1 \overline{\mathrm{o}}$ ' yāda 'tî mē'ayin hēmmāh "I do not know from where they came" (v.4c), which is not found in the Greek version, because in her work as a prostitute, she need not know from where all her customers came. These words coming from her confirm and highlight her social status.

Her full blown deceit is in verse 5 where, continuing her intervention and still referring to the spies simply as hā'ănāšîm and using the same phrase lō' yāda 'tî "I do not know" as in v.4c, she convinced the king's messengers to leave her house. Her words were strong and persuasive enough as to distract the envoys from thinking of searching for the spies in her house. The messengers, and the king intended, were outwitted by this woman who is now in control of the spies and of the entire city. She even commanded the envoys as she pretended to advise them: riḍpû mahēr 'ahărêhem kî taśśîgûm "pursue them quickly for you can overtake them" (v.5b). The men sent by the king and now craftily sent away by Rahab are presented in the narrative as naive, easily convinced and tossed about by a woman. "In committing her life to the people of God, she was not lowly at all, but even wiser than the king of Jericho" [19]. In 2 Samuel 17:17-22 a woman also saved the lives of two men, Jonathan and Ahimaaz, using similar tactics as Rahab did. She helped them escape without being caught by their pursuers. Jael, wife of Heber, in Judges 4:18-20, received Sisera into her house, but her protection was momentary for she killed him with a peg. Rahab on the other hand preserved life; she lied to achieve this. In this way, her lying may not be considered sinful [20] because the breaking of a lesser law so as to keep a higher, that is, preservation of life in this context, is not sin [21].

Verse 6 explains how Rahab preserved the two spies whom she received into her house; it gives a hint on the nature of her house, and provides a clue on her other possible means of earning a living apart from her social status as a prostitute. "Rahab's profession, as noted, was one that put women on the margins of Israelite society. It can be imagined that to survive, such a woman had to be independent, defiant and perceptive as well. Rahab put all these traits to work in the story" [19]. Rahab's house had a gā $\bar{g}$ which is the Hebrew word for a flat roof upon which one may walk. This can serve as spreading ground, especially for grain and other farm produce. Actually, in the text we know that Rahab arranged on this flat roof pištê hā'ẹs "stalks of flax". These must have been abundant enough as to be able to cover the two men and hid them from being discovered by possible intruders. Pēšet "flask, linen" has its botanic name as linum usitatissimum. Pēšet "flask, linen" is also mention in Genesis 41:41; Exodus 25:4; Leviticus 6:10; Leviticus 6:10; Deuteronomy 22:11; 1 Samuel 2:18; Isaiah 42:3; Matthew 27:59; Mark 15:46; John 19:40; Revelation 18:12. It is known as the world's oldest textiles and it takes some significant labour to prepare linen fibres from its stalks. These stalks are used for fibre, sails, cloth, curtains, wicks for lamps, mummy wrappings, cartonnage (that is, linen and papyrus) used for mummy masks. The seeds are also highly useful for they are utilised as linseed oil. They are also medically useful for oil prescribed as demulcent, emollient, and laxative as well as remedy for burns [22]. Rahab had enough of these stalks in her house when the spies arrived. She was most likely a very busy woman who made good use of her time cultivating flask [23], preparing their fibres and using the raw material for some other products [24].

\subsubsection{Rahab's Profession of Faith in YHWH (vv.8-14)}

This second basic dialogue is between Rahab and the two spies who are now lying down on her roof covered with pištê hā'ēs "stalks of flax". Her adherence to the new faith is most likely implied in her movement to the two men whom she was hiding on the roof of her house. The narrator highlights this movement with some alliteration and assonance in v.8.b: 'āl $\mathbf{e}^{\mathrm{e}} \mathrm{a} h$ 'ǎlêhem 'al-haggāg "she went up to them to the roof'. She went up to them and introduced her speech with the same phrase, lō' yāda 'tî "I do not know", she used negatively, in the dialogue with her people. In her conversation with the two men she knows, yāda "tî "I know". What she knew was YHWH's great deeds for Israel in the past. Like most confessions of faith in the Old Testament, her profession of faith was preceded by remembrance of marvellous deeds of YHWH. What was it she knew? She delineated them one after another. Before she enumerated them she first made an inference which was also part of what she knew: "that YHWH has given the land to you" (v.9a). This, certainly did not represent the feelings 
of her fellow townsmen and women [25], otherwise they would not have sought to defend themselves by pursing the spies.

She knew that the Lord has given their land to Israel and this knowledge which her people also shared but did not want to admit the reality rendered them panic-stricken. Rahab described the situation with the same words (cf. v.9) employed in the victory song of Moses (Exodus 15:15-16). Terror, dread ('êmāh) of the people of Israel fell upon them and they were disheartened, melted away (mûg) just as the inhabitants of Canaan melted away at the time of Moses (Exodus 15:15).

Her knowledge and that of her people came from what they heard about YHWH and his people. Thus she continued her speech in v.10 with the verb šăma"nû "we have heard"; this verbal root is found at very strategic points in the first part of the Book of Joshua [26] and it is often in the contexts about other nations hearing YHWH's marvellous deeds in the past. In Joshua 5:1, for instance, the Amorites and all the kings of Canaan heard that the YHWH dried up the waters of the Jordan for the Israelites. In Josh 7:9 Joshua lamented that the Canaanites and all the inhabitants of the land would hear about the misfortune that YHWH would to fall on Israel. In Joshua 9:1 a conglomeration of other nations gathered together to fight Israel when these nations heard about them. Consequently, the Gibeonites (Joshua 9:1) acted with cunning against these other nations when they heard what Joshua had done to Jericho and Ai. Finally, in Joshua 10:1-2 King Adonizedek of Jerusalem was greatly frightened when he heard how Joshua had destroyed Ai. Rahab and her people have also heard about YHWH and this was the foundation of her faith.

She knew God through experience of history [27], and the rest of her speech that reached its climax in affirming the supremacy of YHWH in v.11 recalls this history. First, Rahab and her people heard about Exodus, how Israel came out of Egypt, particularly the miraculous passage through the Red Sea (Exodus 14). They heard how the Israelites exterminated the kings of Amorites, Sihon and Og, beyond the Jordan (Numbers 21:21-35; Deuteronomy 2:26-37). All these made them lose courage because history has proved that YHWH 'ělōhêkem hû' 'ělōhîm baššāmayim mimma'al we'al-hā'āreș mittāhạ "The Lord your God is indeed God in heaven above and on earth below" (v.11). In fact, all Rahab's words and actions towards the two Israelites spies were motivated by this protestation of faith in YHWH. The risk she took in hiding them in her house, her deceitful words to the king's emissaries were all because of her faith in YHWH whom she acknowledged to be a universal God. In point of fact, the phrase, "heaven above and earth below", is merismos ("an enumeration of the parts of a whole") [5] referring to the whole world. This may not appear as a profession of monotheism [27]; however, it can be inferred from her words. The universalistic character of YHWH as Rahab affirms makes him supreme over all and renders other gods almost non-existent.

Truly Rahab's confession has so much in common with profession of monotheistic faith in YHWH according to Deuteronomy 4:39: "So acknowledge today and take to heart that the Lord is God in heaven above and on the earth beneath; there is no other". Besides the monotheistic phrase, 'ên 'ôd " there is no other" in Deuteronomy 4:39, Rahab's words are the exact words, YHWH 'ělōhêkem hû' 'ělōhîm baššāmayim mimma 'al w'al-hā'āreș mittāhat "The Lord your God is indeed God in heaven above and on earth below" (v.11), are the same as in Deuteronomy. This might confirm the opinion that she did not as such affirm monotheism which

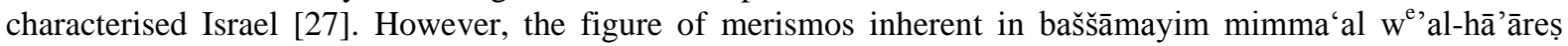
mittāhat "in heaven above and on earth below" is made explicit in the appositional phrase, 'ên 'ôd "there is no other" that follows this confession of faith in Deuteronomy 4:49. Rahab knew the name of Israel's God and she called him by this name in this dialogue, thereby identifying fully with the spies and the rest of Israelites. Her conversion is radical and holistic for in Joshua 6:25 it is said that she lived in Israel throughout her life [28].

Rahab's recognition of YHWH's sovereignty in heaven above as on earth beneath motivated the request she made of the spies and through them the rest of Israelites, to spare her and her family when they besiege Jericho. She also based this request on the kindness she showed them (vv.12-13). In this request she first introduced it in a general way (v.12) without specifying its content. She urged them to swear by YHWH and she was persuasive in her speech. She has shown them hesed "kindness" by saving them from her people. Even before she mentioned the content of her request, she demanded a sign of good faith from them ûn tattem lî 'ôt "ěmet "Give me a sign of good faith". It is observed that this phrase is not in the Septuagint. The Greek translators might have considered it unnecessary because the first part of the same verse already conveys the intention of Rahab. She asked the spies to swear and they did (cf.v.17). It is observed that this phrase is not in the Septuagint. The Greek translators might have considered it unnecessary because the first part of the same verse already conveys the intention of Rahab. She asked the spies to swear and they did (cf.v.17). In Joshua 9 the leaders of Israel swore an oath that they would save the Gibeonites from destruction; they did not violate the oath even when they discovered that they had been deceived by the Gibeonites. In v.13 Rahab made her request explicit: to spare her life and all her family members. Appropriating the two key words, hesed and"ěmet in her request the spies agreed to her request on the condition that she would keep their mission secret. 


\subsubsection{Rahab's saving instruction (vv.15-21)}

This third basic dialogue in Josh 2 took place at the wall of the city as Rahab prepared the two spies to escape from Jericho. Still motivated by her faith in God's sovereignty she continued her act of kindness to the Israelites whose faith she confessed. The position of Rahab's house was of great advantage for her kindness towards the spies. According to the Hebrew version of v.15, the window of her house was part of the city wall; hence it was easier for her to work out the escape of the two men. As a marginal woman by profession she lived on the edges of society symbolised here by the position of her house. She used a rope, hebel. In the present verse the Septuagint omitted this word and a greater part of the verse that describes her house as being situated at the wall of the city. Some believe that it was the same cord that they asked him in v.18 to tie on the window of her house [29], the same window through which they escaped from the city. If it was the same, the narrator must have deferred its full description until v.18; because in v. 15 when the cord was serving its purpose for the two men, it was called hebel "rope". In verse 18 when the spies were instructing the woman on how to use it for her own escape a very rare word, in fact hapax legomenon, tiqwāh "cord", is used; its colour is also described as crimson, šannî. Tiqwāh "cord" is actually in a construct chain in the text with another Hebrew term for cord, thread, or string hût which was perhaps inserted here for emphasis. The crimson colour of the thread reminds one of the blood which the Israelites were asked to sprinkle at their lintels during the last plague in Egypt (Exodus 12:7). Just as this blood was a sign of their salvation, the crimson string on Rahab's window would be a sign that she and her family would be saved; thus, the red sign was meant to be apotropaic (intended to ward off evil or bad luck) in its function.

In this final dialogue with the spies she instructed them to hide for three days in the hill country before continuing their journey back to Shittim. She must have calculated the length of time her people would spend in searching for the men. Rahab continued to play very decisive role in this narrative. According to the narrator, she was the person that lowered the men down, wattôridēm, with a cord through her window. Just as she brought them up, he'ělatam, to the flat roof of her house when they entered (v.6), she now lowered them when they were to leave. She gave them precise instruction on how to evade being caught even when they have left her house and the city. In point of fact, "she is a woman in a man's world. As a woman she acts with courage and freedom" [30]. The courage she exhibited is attributed to her faith in Israel's God who had already instilled terror in all who heard about the marvellous deeds he wrought for his people.

Rahab agreed to the condition that the spies gave her; first to keep their mission confidential; second to tie the crimson cord on her window; third to make sure that all her people be gathered in the same house where the red cord would be. She tied the cord as soon as they left. Her encouragement and co-operation with the spies generated the report the two men gave to Joshua: "Truly the Lord has given all the land into our hands; moreover all the inhabitants of the land melt in fear before us" (Joshua 2:24). They kept the oath they swore to the woman and saved her life and those of her people (Joshua 6:22-25).

\section{Rahab in Jewish Traditions}

Extra-Biblical Jewish traditions have much more than we read in the Bible to convey about the person of Rahab. It is from these traditions that we derive more information about her, who, according to Joshua 6:25, lived among Israelites from the time they entered Canaan to the end of her life and her memories were passed on and preserved by early Christians. These traditions perceive more beyond the act of kindness she showed the spies. Furthermore, there is tendency in these to re-interpret her social status. In the Haggadah (This refers to rabbinical literature on biblical stories; they are those sections of the Talmud and other rabbinical literature that deal with biblical narrative and stories and legends on biblical themes, rather than with religious law and regulations), for instance,

Rahab was one of the four beautiful women in history. The mere mention of her name sufficed to excite desire. At the age of ten Rahab became a prostitute. There was not a prince or ruler who did not have relations with her. Because of this she was well informed about events outside of Jericho. Rahab became a righteous proselyte and married Joshua. She was the ancestress of eight prophets, among them Jeremiah, who were also priests, and of the prophetess Huldah. Her conversion is regarded as more complete than that of Jethro and Naaman for, unlike them, she acknowledged that God of Israel is the only God both in heaven and on earth [31].

Most of the things included in this tradition are not mentioned in what we read about Rahab in the Bible. In these traditions, she was one of the four beautiful women in Jewish history; the other three were Sarah, Abigail and Esther [32]. The eight prophets from Rahab were Jeremiah, Hilkiah, Seraiah, Mahseiah, Baruch, Neriah, Hanamel and Shalom [32]. The text cited above, however, makes a fundamental point which seems to justify Rahab's importance and inclusion in Jewish and Christian traditions: "Rahab became the prototype of the proselyte who abandoned a life of sin to accept the faith of Israel; and so she is often presented as a living example of the effectiveness of Israel's proselytization when Israel is faithful to its calling" [6]. Judaism finds in Rahab an example of Israel's faithfulness to the mission God entrusted to his people, to make his name known 
to all the earth. This mission of Israel is central to the Second part of Isaiah for, "by the example of the chosen people and the lessons of its history the non-Jewish nations also are summoned to serve one God" [33]. This was the case with Rahab and her people. She believed in YHWH through what she heard about his deeds and his people. "According to this tradition, the fact that a proselyte and former prostitute could achieve such a name for herself in the annals of Jewish history proved that repentance can work salvation for anyone no matter how great his past sins" [29]. Rahab did achieve this and her name is engraved in history; this is her greatness.

A Jewish historian, Flavius Josephus, had a picture of Rahab that seems apologetic, defending Rahab's image. In his history of Israel, where he mentioned Rahab, she is not presented as a prostitute but as an innkeeper who preserved the life of her customers [34]. With Josephus' depiction of Rahab as an hotelier, her disturbing status as a prostitute is mitigate; otherwise, how could a person of such repute be considered as Israel's worthy ancestress. Josephus' concern however is clear because he was writing for the Roman lords of his time and he felt great obligation to portray a good image of his people Israel [19].

According to the Midrash, there are four things negative about Rahab before her conversion: she was called Rahab the harlot; she dwelt at the outside of the city; she lived in the land of Canaan whose people were harsh and evil; she resided in Jericho which was destined for extinction [32]. The same Jewish tradition teaches that Rahab was a prostitute for forty years and that she was converted at the age of fifty. After her conversion, she became a symbol for future generations. It was in this new perspective about her that the NT received her as an ancestress of Jesus the Messiah, an exemplary OT faith and a model of Christian faith with good works.

\section{Rahab in the New Testament}

The New Testament mentions Rahab in three texts that continue the Jewish tradition of seeing beyond the apparent personality of a mere prostitute. She appears first in the Matthean genealogy of Jesus the Messiah (Matthew 1:1-17). In verse 5 of this text, Rahab is the Mother of Boaz and the wife of Salmon. The personal name Salmon or Sala or Salmah appears only in genealogies, specifically of Davidic lineage. Besides Matthew 1:5, he is mentioned again in Ruth 4:20-21 and Luke 3:32. Similar name is found in 1 Chronicles 2:51-55 where he is called the father of Bethlehem and others. It is of interest that in the genealogy of Jesus according to Matthew, Rahab is one of the four women mentioned before Mary the Mother of Jesus. These women are Tamar, Rahab, Ruth and Uriah's wife (Bathsheba). A close look at the lives and personalities of these women elicits a trait they all had in common: they had irregular scandalous marital unions, an overt object of calumny in each case. In spite of this, they were included in God's plan for our salvation and became ancestress of Jesus. "The women then serve as a reminder that God often works in the most unusual ways and that to be open to his sovereign activity is to be prepared for the surprising" [35]. Matthew might have intentionally inserted them in the genealogy of Jesus to prefigure Mary, the Mother of Jesus whose pregnancy involved extraordinary circumstance [36]. God's ways are not our ways! Rahab belonged to this group of privileged women whom God unconditionally chose to fulfil his plan for human salvation.

The second New Testament text that mentions Rahab is the Letter to the Hebrews 11:31: "By faith Rahab the prostitute did not perish with those who were disobedient, because she had received the spies in peace". The context of this in the Letter to the Hebrew is the catalogue of those who exercised faith in the Old Testament. Hebrew 11:1 introduces this list of believers in these words: "Now faith is the assurance of things hoped for, the conviction of things not seen". Rahab, according to the text, was one of those who believed. The inhabitants of Jericho who died in the siege against the city were those who did not believe (Hebrews 11:31). She received the spies and her faith made her preserve them from imminent danger. In this list of heroes of faith, Rahab and Sarah (Hebrews 11:11) are the only women mentioned. Rahab believed in God's marvelous deeds which she and her people heard. While other did not believe, she believed and helped the spies to achieve their mission, knowing that YHWH is a sovereign God in heaven and on earth.

With a rhetorical question, of which the audience already had the answer and affirmative indeed, James 2:25 mentions Rahab as an example of faith with works: "Likewise, was not Rahab the prostitute also justified by works when she welcomed the messengers and sent them out by another road?" This is an allusion to Joshua 2 and 6:22-25; Rahab proved her faith in good works of showing hospitality to the two Israelite spies and her life was spared when her city was being destroyed. In this way, Rahab, in the context that the author of the letter of James was writing, was justified; that is, she was saved by her good works. The context in this New Testament text is to demonstrate that sola fides is not enough in Christian life; faith must be proved in works. In fact, the immediate context of this in James is 2:14-26, where the author convincingly argued that faith without works is dead: "For just as the body without the spirit is dead, so faith without works is also dead" (James 2:26). Rahab believed in the supremacy of Israel's God and she worked accordingly to propagate his course. Following the argument of James, Rahab's faith proved in good work saved her from physical death and also from spiritual death for she became one of the chosen people of God by her adherence to this faith.

Similarly, early Christian writings like I Clement 12:1-8 followed the Jewish traditions and the New Testament in praising the faith of Rahab; she was saved, according to I Clement 12:1, through her faith and 
hospitality. The scarlet cord that the spies asked her to hang on her window was a sign of prophecy in the action of this woman: "And thus they made it manifest that redemption should flow through the blood of the Lord to all them that believe and hope in God" (1 Clement 12:7) [37]. The author of 1 Clement saw in this scarlet string prefiguration of the saving blood of Jesus just as the blood on Israelites' lintels in Exodus 14 prefigured the salvific death of Jesus. In the same way, Saint Jerome explained that "with a mystic reference to the shedding of blood, it was a scarlet cord which the harlot Rahab (a type of the church) hung in her window to preserve her house in the destruction of Jericho" [38].

\section{Exploring the Old Testament Backgrounds of the Faith of Rahab}

"Who has directed the spirit of the Lord, or as his counselor has instructed him? Whom did he consult for his enlightenment, and who taught him the path of justice? Who taught him knowledge, and showed him the way of understanding?" (Isaiah 40:13-14). This sequence of rhetorical questions expecting answers in the negative is meant to aid human reflection on many inexplicable divine surprises in the Bible. The psalmist summed them up with an exclamation: "Our God is in the heavens; he does whatever he pleases!" (Psalm 115:3). Moses, whom God prepared and called to lead his people and who suffered greatly for the course of this God, was denied the Promised Land for which the hope of the people fervently glowed. A divine surprise indeed! Was Rebecca not unjust when she carefully planned and executed treason in the house of Isaac? Esau was deprived of his birthright and Isaac did not reverse the apparent blessing he mistakenly bestowed on his second son instead of his primogenitor. God sanctioned this action and it was part of his divine plan for our salvation; it is surprising to all of us who today read and pray these narratives. Lineage of Israel's descendants, for instance, had to continue through the son of Bathsheba, in spite of how she entered David's house and David's atrocity to secure and keep her. What about Rahab? Why did a prostitute contribute so immensely to the success of the conquest of the Promised Land? She could have disappeared from the scene; rather, she dwells in Israel to this day (Josh 6:25) for her name remains indelible in the history of Israel and of our salvation. The Messiah of human race came through her!

There is always a necessary price to be paid in the life of faith for in doing this "the man of faith gains strength by putting himself in the hands of God who is faithful" [1]. Rahab belongs to the group of those who paid highly for their faith in God. This might explain why Jewish traditions hold her in great esteem and she is included in the list of heroes of faith in the Old Testament. When God called Abraham, he abandoned all and followed him (Genesis 12). He left land and kinsmen and women. This father of faith paid for his faith when he, through faith in God, opted to sacrifice his only son even when he had been promised that the number of his children would be like sand by the seashore. All the prophets sacrificed their lives and all they had for their faith in God and for an authentic transmission of the same faith. Rahab risked his life for her faith in the true God she discovered in the God of Israel. She moved from her social status to be a model of a pious proselyte, a model of a believing Jew, a type of the Church, according to Saint Jerome. Like Abraham she moved from where she was and embraced a new life and nation because of her faith. This sacrifice emboldened her in her work of faith.

The story of Rahab can be read along with those texts of the Old Testament that present the extension of Israel's faith in YHWH to non-Israelites; it is faith without frontiers. Ruth's faithfulness to Naomi, her mother-in-law, included also a profession of faith in Naomi's God: "Do not press me to leave you or to turn back from following you! Where you go, I will go; where you lodge, I will lodge; your people shall be my people, and your God my God" (Ruth 1:16). She ended up as an important figure in the line of David, an ancestress of David and of the Messiah. After his miraculous cure by Elisha, Naaman confessing her faith in God exclaimed: "Now I know that there is no God in all the earth except in Israel" (2 Kings 5:15). Rahab, a non-Israelite, received this faith and attained the status of a model of faith in Israel.

\section{Conclusion}

The story of Rahab, who rose from her marginal status to a heroine of faith in God, epitomises the nature of faith as a gratuitous and unconditional gift from God. God initiates faith in us and sustains it. Our response is the faith which we make active through works. None of us can merit this gift. Rahab did not merit it. From her speech, all in her city heard about God's marvellous needs and they understood them differently. While others were moved to self defence, these divine deeds engendered faith in a trivial woman from whom no one least expected it. She received it and was fast in activating it selflessly.

Rahab's life teaches us that God meets each person in his or her state in life. He invites us in what we are and from where we are. He expects us to begin our response to his invitation from our varied states in life. Our salvation depends so much on how we utilise our "present" in answering God's call. He met Rahab as a prostitute and she used her position to further God's plan for human salvation. She was not afraid to rise from her social status, from where she was and from what she was.

Therefore, Rahab's apparent treason and seemingly unpatriotic action was actually God's design, a divine surprise that is beyond human understanding. Jewish traditions and early Christians who perceived 
beyond Rahab's appearance grasped this intricate divine puzzle; they unremittingly projected the divine mystery that gradually evolved in her person. They understood that "faith is not a light which scatters all our darkness, but a lamp which guides our steps in the night and suffices for the journey" [1].

\section{REFERENCES}

[1] Pope Francis, Lumen Fidei: Encyclical Letter (Vatican City: Libreria Editrice Vaticana, 2013).

[2] J. P. Healey, "Faith", The Anchor Bible Dictionary, 2 (London: Doubleday, 1992) 744-760.

[3] M. D. Coogan, "Joshua", The New Jerome Biblical Commentary (London: Geoffrey Chapman, 1992) 110-112.

[4] P. Béré, Le second Serviteur de Yhwh. Un portrait exégétique de Josué dans le livre éponyme; Orbis Biblicus et Orientalis - OBO 253 (Fribourg: Academic Press, 2012).

[5] E.W. Bullinger, Figures of Speech used in the Bible Explained and Illustrated (Grand Rapids, Michigan: Baker Book House, 2003).

[6] J.A. Soggin, Joshua: A Commentary (London: SCM Press, 1988).

[7] H.D. Preuss, "bô'", Theological Dictionary of the Old Testament, 2 (Grand Rapids, Michigan: Eerdmans, 1999) $20-49$.

[8] B.K. Waltke - M. O’Connor, An Introduction to Biblical Hebrew Syntax (Winona Lake, Indiana: Eisenbrauns, 1990).

[9] J. L. Ska, "Our Fathers have told us": Introduction to the Analysis of Hebrew Narratives (Subsidia Biblica 13; Rome: Editice Pontificio Istituto Biblico, 2000).

[10] J. C. Slayton, "Shittim", The Anchor Bible Dictionary, 5 (London: Doubleday, 1992) 1222-1223.

[11] J.L. McKenzie, "Shittim", Dictionary of the Bible (Milwaukee: The Bruce Publishing Company, 1965$) 810$.

[12] T.A. Holland - E. Netzer, "Jericho", The Anchor Bible Dictionary, 3 (London: Doubleday, 1992) 723-740.

[13] D. K. Berry, "Rehabiah", The Anchor Bible Dictionary, 5 (London: Doubleday, 1992) 660.

[14] L. J. Greenspoon, "Rahab", The Anchor Bible Dictionary, 5 (London: Doubleday, 1992) 611-612.

[15] J. Day, God's Conflict with the Dragon and the Sea; Cambridge 1985; and "Rahab (Dragon)", The Anchor Bible Dictionary, 5 (London: Doubleday, 1992) 610-611).

[16] S. Erlandsson, "zānāh", Theological Dictionary of the Old Testament, 4 (Grand Rapids, Michigan: Eerdmans, 1997) 99.

[17] F.J. Stendebach, "Regel", Theological Dictionary of the Old Testament, 13 (Grand Rapids, Michigan: Eerdmans, 2004$) 322$.

[18] T. Frymer-Kensky, "Reading Rahab", Teheilla le-Moshe: Biblical and Judaic Studies in honor of Moshe Greenberg (Winona Lake, Indiana: Eisenbrauns, 1997) 57-68.

[19] M. F. Vamosh, Women at the time of the Bible (Herzlia, Israel: Palphot, 2007) 99-104

[20] W. Jackson, "Does the Bible Sanction Rahab's Lying?" https://www.christiancourier.com/articles/1324-does-the-bible-sanctionrahabs-lying (Accessed 20 Sept 2013)

[21] P. Barnes, "Was Rahab's lie a sin?" The Reformed Theological Review, 54, 1995, 1-9.

[22] I. Jacob - W. Jacob, "Flora", The Anchor Bible Dictionary vol. II (London: Doubleday, 1992) 815.

[23] J. Aust, "Profiles of Faith: Rahab - From Harlot to Heroine", http://www.ucg.org/faith/profiles-faith-rahab-harlot-heroine (Accessed 13 Sept 2013).

[24] N. Mindel, "Rahab", http://www.chabad.org/library/article_cdo/aid/112075/jewish/Rahab.htm (Accessed 18 Sept 2013).

[25] J. Garstang, Joshua- Judges: The Foundations of Bible History (Grand Rapids, Michigan: Kregel Publications, 1978).

[26] K. A. Deurloo, "Spiel mit und Verweis auf Torah-Worte in Joshua 2-6; 9" Dielheimer Blätter zum ALten Testament und seiner Rezeption in der Alten Kirchen (1992) 70-80.

[27] B. D. Lerner, "Rahab the Harlot and other Philosophers of Religion", The Jewish Bible Quarterly, 28, 2000, 52-55.

[28] E. Sánchez Cetina, "Joshua", The International Bible Commentary: A Catholic and Ecumenical Commentary for the Twenty-First Century; W.R. Farmer (ed.) (Collegeville, Minnesota: The Liturgical Press, 1998) 525-547.

[29] C. Cohen, "Rahab", Encyclopaedia Judaica, 13 (Jerusalem: Keter Publishing House, 1996) 1514-1515.

[30] B. C. Birch et al., A Theological Introduction to the Old Testament (Nashville: Abingdon Press, $2005^{2}$ ).

[31] Y. Kaufmann, Sefer Yeshoshu'a (1959) in the Aggadah: Ginzberg, Legends, index (This text and the reference are taken from Encylopaedia Judaica vol.13 (Jerusalem: Keter Publishing, 1996) 1515.

[32] T. Kadari, "Rahab: Midrash and Aggadah", Jewish Women: A Comprehensive Historical Encyclopedia. 1 March 2009. Jewish Women's Archive. (Accessed on September 25, 2013) <http://jwa.org/encyclopedia/article/rahab-midrash-and-aggadah>.

[33] The New Jerusalem Bible; London: Doubleday, 1990.

[34] J. Flavius, Antiquities of the Jews Book V Chapter 1 Section 2; The Complete Works of Josephus; translated by William Whiston (Grand Rapids, Michigan: Kregel Publications, 1993).

[35] D. A. Hagner, Matthew 1-13 (Word Biblical Commentary, 33A; Nashville: Thomas Nelson Publishers, 1993$) 10$.

[36] W.D. Davies - D.C. Allison, A Critical and Exegetical Commentary on the Gospel according to Matthew, 1 (Edinburg: T.\&T. Clark, 1988) 170-171.

[37] BibleWorks Version 8

[38] Saint Jerome, Letters and Select Works, translated by W.H. Fremantle; A Select Library of Nicene and Post-Nicene Fathers of the Christian Church, 6 (Grand Rapids, Michigan: Eerdmans Publishing Company 1996) 90-91. 